\title{
Choroid plexus carcinoma in a cow
}

\author{
Carcinoma de plexo coróide em um bovino
}

\section{Fabiano José Ferreira de Sant’Ana' ${ }^{I}$ Adriane Loy Gabriel ${ }^{I}$ Glaucia Denise Kommers ${ }^{I I}$ Claudio Severo Lombardo de Barros ${ }^{\mathrm{II}^{*}}$}

\section{ABSTRACT}

A red, firm $3.5 \times 3.0 \times 3.0 \mathrm{~cm}$ mass was found within the right lateral ventricle, compressing the hippocampus and thalamus of the brain of a 4-year-old cow. The pituitary was enlarged and firm. Histologically, both the brain and pituitary masses consisted of moderately pleomorphic epithelial cells arranged as rosettes or sheets supported by a delicate fibrovascular stroma. Based on anatomical localization, histopathological and immunohistochemical findings, a diagnosis of choroid plexus carcinoma with pituitary metastasis was made.
\end{abstract}

- NOTE -
Key words: cattle diseases, neoplasms, neuropathology.

\section{RESUMO}

Um massa vermelha e firme de $3,5 \times 3,0 \times 3,0 \mathrm{~cm}$ foi observada no ventrículo lateral, comprimindo o hipocampo e tálamo do cérebro de uma vaca de quatro anos de idade. A pituitária estava aumentada de volume e firme. Histologicamente, tanto a massa do cérebro, quanto da pituitária, consistiam de células epiteliais moderadamente pleomórficas, arranjadas em rosetas ou cordões e apoiadas em um delicado estroma fibrovascular. Com base na localização anatômica e nos achados histopatológicos e imuno-histoquímicos, foi realizado um diagnóstico de carcinoma de plexo coróide com metástase para a pituitária.

Palavras-chave: doenças de bovinos, neoplasmas, neuropatologia.

Central nervous system (CNS) tumors are infrequently described in cattle (SANCHES et al., 2000;
BARROS et al., 2006). According to cellular differentiation, number of mitosis and local invasion, choroid plexus neoplasms can be classified as choroid plexus papillomas or carcinomas (KOESTNER et al., 1999). In dogs, these tumors affect especially middleaged male animals (RIBAS et al., 1989; SUMMERS et al., 1995) and occur adjacent to or within ventricular cavities (ZAKI \& NAFE, 1980; WESTWORTH et al., 2008). In humans, the choroid plexus neoplasms occur more frequently in the lateral ventricles, mainly in children (PENCALET et al., 1998). Choroid plexus carcinomas (CPC) are rare neoplasms in all species and are distinguished from papillomas based on cellular pleomorfism, nuclear atypia, high mitotic rate, local invasion and metastases (KOESTNER \& HIGGINS, 2002). The current paper describes the clinical, pathological and immunohistochemical findings of a case of CPC in a cow.

A 4-year-old cow had a history of anorexia, weight loss, uncoordinated gait and corneal opacity of unknown duration. It was found in sternal recumbency within a shallow pond and remained in this position until death. The fresh whole brain and a tissue block formed by the Gasserian ganglia, carotid rete mirabile and pituitary gland were submitted for histopathological evaluation. The right telencephalic

IPrograma de Pós-graduação em Medicina Veterinária, área de concentração em Patologia Veterinária, Universidade Federal de Santa Maria (UFSM), Santa Maria, RS, Brasil.

IILaboratório de Patologia Veterinária, Departamento de Patologia, UFSM, 97105-900, Santa Maria, RS, Brasil. E-mail: claudioslbarros@uol.om.br.*Autor para correspondência. 
hemisphere was slightly larger than the left. The whole $10 \%$ formalin fixed brain was sectioned at $1 \mathrm{~cm}$ interval and both sides of each section were evaluated grossly. A red, firm $3.5 \times 3.0 \times 3.0 \mathrm{~cm}$ mass was found within the right lateral ventricle compressing the hippocampus and thalamus (Figure 1A). The pituitary was enlarged $(2.5 \times 2.0 \times 2.0 \mathrm{~cm})$, firm and its cut surface was pale brown with small yellowish areas.

Samples from the brain and pituitary were processed by routine methods for histopathological evaluation. Sections were stained with hematoxylin and eosin and immunohistochemistry (IHC) using streptavidin-biotin-peroxidase complex ${ }^{\mathrm{a}}$ and 3,3diaminobenzidin ${ }^{\mathrm{b}}$. For IHC the following antibodies were applied in proper dilutions on the tumor sections: anti-vimentin $^{\mathrm{c}}$ (monoclonal, 1:100), anti-glial fibrillary acidic protein (GFAP) ${ }^{\mathrm{c}}$ (polyclonal, 1:1.000) and antibovine pancytokeratin (polyclonal, 1:500) ${ }^{\mathrm{c}}$. IHC sections were counterstained with Harris hematoxylin. Positive controls for IHC consisted of normal brain tissue including choroid plexus. For negative controls, the primary antibodies were replaced with PBS.

Microscopically, the brain mass consisted of moderately pleomorphic epithelial cells that were arranged as rosettes or sheets supported by a delicate fibrovascular stroma. The cells were columnar, ciliated and exhibited eosinophilic cytoplasm and hipochromatic, oval to round nuclei, localized in the basal domain of the cell, with 2-5 prominent nucleoli. Two to four mitoses per high power field were observed. Numerous and extensive areas of necrosis with hemorrhage were frequent (Figure 1B). In the

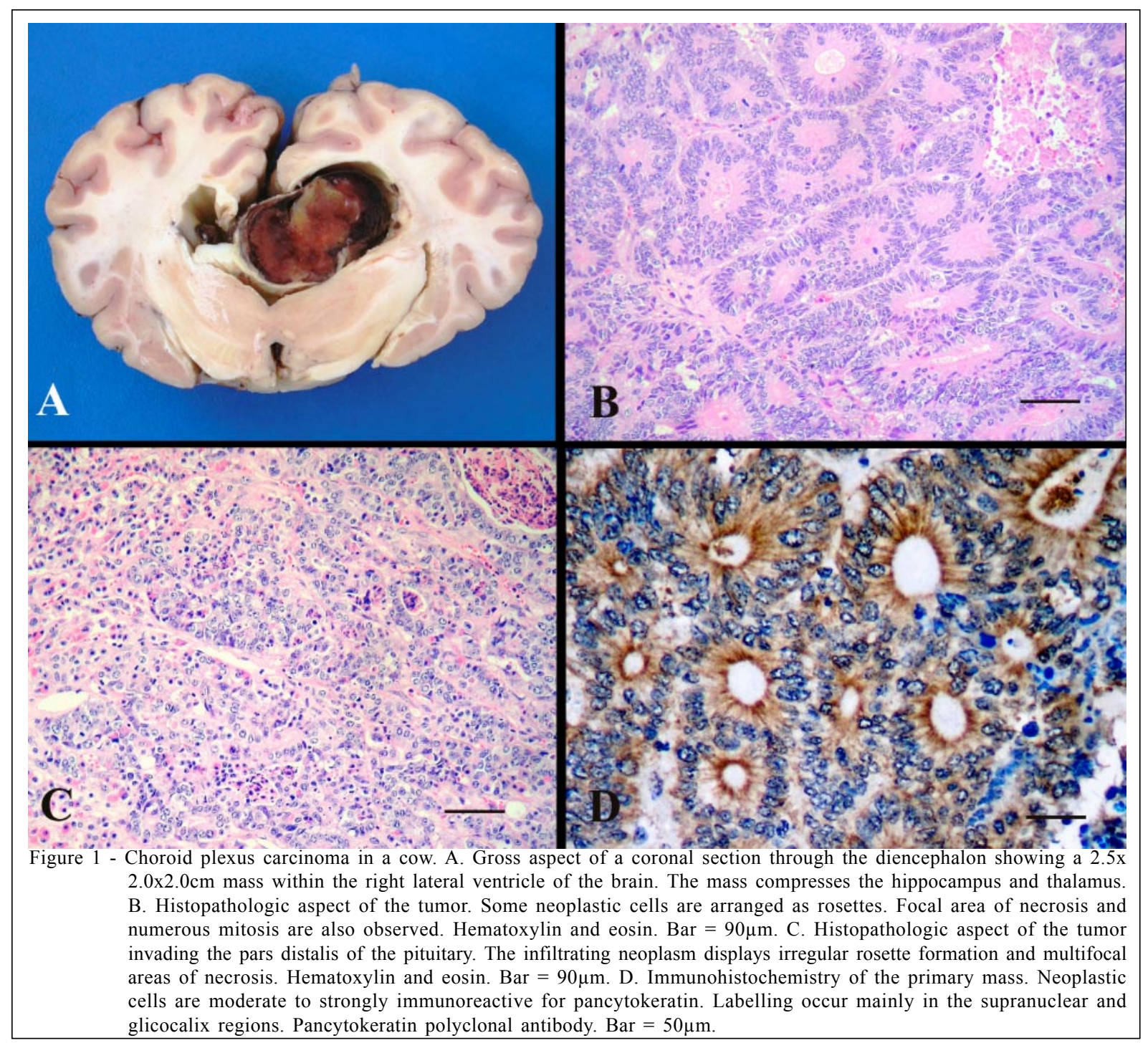

Ciência Rural, v.39, n.7, out, 2009. 
pituitary an histologically similar markedly invasive neoplasm was observed (Figure 1C). On IHC evaluation of the brain and pituitary neoplasms a moderate multifocal labeling for pancytokeratin mainly in the apical domain of the cell was observed (Figure 1D). There was no labeling for vimentin and GFAP. The labeling for GFAP and pancytokeratin was positive in brain tissue used as control. On the basis of location, histopathological and immunohistochemical findings, a diagnosis of CPC was made.

Clinic signs for cattle with neoplasms of the choroid plexus depend on the anatomical location of the tumor and the resultant compression on adjacent structures. Circling and head tilt to the right side, and ataxia were observed in a case of plexus papilloma of fourth ventricle in a bovine (YAMADA et al., 1998) and progressive ataxia, ventromedial strabismus and hyperaesthesia were reported in a cow with choroid plexus papilloma of the third ventricle (HOENERHOFF et al., 2006). In the present case, the affected cow presented anorexia, weight loss, incoordination and corneal opacity.

Features such as high mitotic rate, marked necrosis, nuclear atypia and solid growth are considered as malignancy indicators for choroid plexus neoplasms (RIBAS et al., 1989; KOESTNER \& HIGGINS, 2002). Metastasis and invasion along the neuraxis should be used as diagnostic criterion for malignancy of choroid plexus neoplasms (KOESTNER et al., 1999). In dogs, this neoplasm metastatize frequently within the ventricular spaces or the meninges (CANTILE et al., 2002). In the present case, high mitotic index, marked cellular pleomorfism, extensive areas of necrosis and hemorrhage and the occurrence of tumor cells in the pituitary similar to those found in the brain tumor were considered critical in favoring the diagnosis of CPC. The pituitary neoplasm was considered metastasis from the CPC, based on the similar cellular features and lack of anatomical continuity between the pituitary and the brain tumor. CPC may spread along cerebrospinal fluid pathways (SHORTRIDGE, 1971; KOESTNER \& HIGGINS, 2002). In these case, no secondary tumor implantation was not observed in any locus along the ventricular system and metastasis could be explained by embolic dissemination.

The differential diagnosis between CPC and papillary ependymoma may be difficult since some histological features of both neoplasms are similar (RIBAS et al., 1989; KOESTNER \& HIGGINS, 2002) which is not since choroid plexus epithelial cells are modified ependymal cells (DELLMANN \& EURELL, 1998). Choroid plexus tumors however have a fibrovascular stroma, while ependymomas possess a fibrillar, non-collagenous background (RIBAS et al., 1989). IHC is the most reliable diagnostic criterion to set apart these two neoplasms. Tumor cells of choroid plexus tumors express cytokeratin while ependymoma cells will express GFAP and vimentin (KOESTNER \& HIGGINS, 2002). Many reports mention the absence cytokeratin immunoreactivity in ependymomas from humans and animals (MIETTINEN et al., 1986; KANEKO et al., 1990; CARRIGAN et al., 1996; KOESTNER \& HIGGINS, 2002; VURAL et al., 2006). Usually choroid plexus tumors in humans express cytokeratin, vimentin to a lesser extent, and rarely GFAP. The expression of these same markers in similar tumors from dogs have been described as variable (WILSON et al., 1989; CANTILE et al., 2002).

In the present report, a rare case of choroid plexus carcinoma in a cow is described. The immunohistochemical evaluation was essential in confirming the diagnosis.

\section{SOURCES AND MANUFACTURERS}

a-Streptavidin-biotin-peroxidase complex, Dako, Carpinteria, California, United States of America (USA).

b-3,3-diaminobenzidin, Sigma Chemical Co., St. Louis, Missouri, USA.

c-Anti-vimentin, anti-glial fibrillary acidic protein (GFAP), and anti-bovine pancytokeratin, Dako, Carpinteria, California, USA

\section{REFERENCES}

BARROS, C.S.L. et al. Neoplasias. In: Doenças do sistema nervoso de bovinos no Brasil. São Paulo: Agnes, 2006. p.185-198.

CANTILE, C. et al. Pathological and immunohistochemical studies of choroid plexus carcinoma of the dog. Journal of Comparative Pathology, v.126, p.183-193, 2002. Available from: <http:// www.sciencedirect.com/science?_ob=MImg\&_imagekey=B6WHW$45 \mathrm{~K} 10 \mathrm{HF}-\mathrm{D}-1 \&$ \& cdi $=6861 \&$ _user $=687358 \&$ \& orig $=$ browse $\&$ cov erDate $=02 \% 2 \mathrm{~F} 28 \% 2 \mathrm{~F} 2002 \& \_\mathrm{sk}=998739997 \& \mathrm{view}=\mathrm{c} \& w \mathrm{whp}=\mathrm{dGLzVlz}-$ zSkzS\&md5=a59bbb51 c453340a504f5d3f0c cbab6b\&ie $=/$ sdarticle.pdf $>$. Accessed: jun. 10, 2009. doi: 10.1053/ jcpa.2002.0544

CARRIGAN, M.J. et al. Equine papillary ependymoma. Veterinary Pathology, v.33, p.77-80, 1996.

DELLMANN, H.D.; EURELL, J. Nervous tissue. In: Textbook of veterinary histology. 5.ed. Baltimore: Williams \& Wilkins, 1998. p.98-99.

HOENERHOFF, M.J. et al. Choroid plexus papilloma in a scottish highland cow. Journal of Comparative Pathology, v.135, p.146-149, 2006. Available from: <http://www.sciencedirect.com/ science?_ob=MImg\&_imagekey=B6WHW-4KTVTV 8-1 $3 \&$ _cdi $=\overline{6} 861 \&$ _user $=687358 \&$ \&orig $=$ browse\&_coverDate $=10 \% 2 \mathrm{~F} 31 \% 2 \mathrm{~F} 2006 \& \mathrm{sk}=998649997 \& \mathrm{view}=\mathrm{c} \& \mathrm{wchp}=\mathrm{dGLbVlz}-$ zSkWA\&md5=471f54565fb774c $21 \mathrm{ab} 587 \mathrm{c} 0 \mathrm{~d} 3946 \mathrm{e} 8 \mathrm{f} \& \mathrm{ie}=/$ sdarticle.pdf $>$. Accessed: jun. 10, 2009. doi: 10.1016/ j.jcpa.2006.04.002. 
KANEKO, Y. et al. Immunohistochemical study of ependymal neoplasms: histological subtypes and glial and epithelial characteristics. Virchows Archives A, v.417, p.97-103, 1990. Available from: <http:/ /www.springerlink.com/content/y38953q257053321/ ? $\mathrm{p}=$ bfa8f343ae114506a3e603f0522857d0\&pi=1>. Accessed: jun. 16, 2009. doi: 10.1007/BF02190526.

KOESTNER, A. et al. Tumors of neuroepithelial tissue. In: Histological classification of tumors of the nervous system of domestic animals. 2.ed. Washington: AFIP, 1999. V.5, p.13-38.

KOESTNER, A.; HIGGINS, R.J. Tumors of the nervous system. In: MEUTEN, D.J. Tumors in domestic animals. 4.ed. Ames: Iowa State University, 2002. p.697-738

MIETTINEN, M. et al. Intermediate filament proteins in choroid plexus and ependyma and their tumors. American Journal of Pathology, v.123, p.231-240, 1986.

PENCALET, G. et al. Papillomas and carcinomas of the choroid plexus in children. Journal of Neurosurgery, v.88, p.521528,1998 .

RIBAS, J.L. et al. A histologic and immunohistochemical study of choroid plexus tumours of the dog. Veterinary Pathology, v.26, p.55-64, 1989.

SANCHES, A.W.D. et al. Doenças do sistema nervoso central em bovinos no Sul do Brasil. Pesquisa Veterinária Brasileira, v.20, p.113-118, 2000. Available from: <http:// www.scielo.br/pdf/pvb/v20n3/2729.pdf $>$. Accessed: jun. 10, 2009. doi: 101590/S0100-736X2000000300005.

SHORTRIDGE, E.H. Neoplasms in cattle. New Zealand Veterinary Journal.v.19, p.5-11, 1971.

SUMMERS, B.A.et al. Tumors of the central nervous system. In: Veterinary neuropathology. St. Louis: Mosby, 1995. p.351-401.

VURAL, S.A. et al. Ventricular ependymoma in a German Shepherd dog. Veterinary Journal, v.172, p.185-187,
2006. Available from: <http://www.sciencedirect.com/ science?_ob=MImg\&_imagekey=B6WXN-4G0B76J-1$1 \&$ _cdi $=7163 \&$ _user $=687358 \&$ \&orig=browse\&_coverDate $=07 \% 2 F 31 \% 2 F 2006 \&$ sk $=998279998 \&$ view $=$ c \&wchp $=$ dGLzVzzzSkzk\&md5=f8ff923 cece $68 \mathrm{f} 635306 \mathrm{cfa} 6539 \mathrm{~d} 630 \mathrm{~b} 7 \& \mathrm{ie}=/$ sdarticle.pdf $>$. Accessed: jun. 10, 2009. doi: 10.1016/ j.tvj1.2005.02.014.

WESTWORTH, D.R. et al. Choroid plexus tumors in 56 dogs (1985-2007). Journal of Veterinary Internal Medicine, v.22, p.1157-1165, 2008. Available from: <http:// www3.interscience.wiley.com/cgi-bin/fulltext/121372008/ PDFSTART $>$. Accessed: jun. 10, 2009. doi: 10.1111/ j.1939.1676.2008.0170.x.

WILSON, R.B. et al. Choroid plexus carcinoma in a dog. Journal of Comparative Pathology, v.100, p.323-326, 1989. Available from: <http://www.sciencedirect.com/ science? ob=ArticleURL\& udi=B6WHW-4DCW279N W \&_us e r $=687358 \&$ \& c over D a t e $=04 \% 2$ F 3 $0 \% 2 \mathrm{~F} 1989 \&$ rdoc $=13 \&$ fmt $=$ high \&_orig $=$ browse\&_srch $=$ docinfo(\%23toc\%236861\%231989\%23998999996\%23520597\%23F LA \%23 display\%23 Volume)\&_cdi=6861\&_sort $=$ d \& _docanchor $=\&$ \& ct $=20 \&$ \& c ct $=$ C $000037899 \&$ version $=1 \&$ _ u r 1 Vers i o $n=0 \&$ u s e rid $=$ 687358\&md5=d6e-9dcd791d6358f6053d2766fea 43a $3>$. Accessed: jun. 16, 2009. doi: 10.1016/0021-9975(89)90110-2.

YAMADA, M. et al. Histopathological and immunohistochemical studies of intracranial nervous-system tumours in four cattle. Journal of Comparative Pathology, v.119, p.75-82, 1998. Available from: $<\mathrm{http}$ // /www.sciencedirect.com/science?_ob=MImg\&_imagekey=B6WHW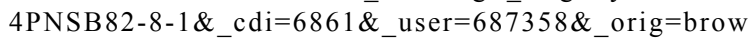 $\mathrm{s}$ e \& $\quad \mathrm{c}$ o $\quad \mathrm{v}$ e $\mathrm{r}$ D a t $\mathrm{e}=\begin{array}{llllllll}0 & 7 & \% & 2 & \mathrm{~F} & 3 & 1 & \%\end{array}$ 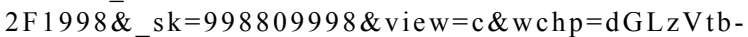 zSkzk\&md5=d37324dcb90c360e01b545f429ac4d8b\&ie=/sdarticle.pdf $>$. Accessed: jun. 10, 2009. doi: 10.1016/S0021-9975(98)80073-X.

ZAKI, F.A.; NAFE, LA. Choroid plexus tumors in the dog. Journal of the American Veterinary Medical Association, v.176, p. 328-330, 1980. 